\title{
PEMODELAN GENERAL REGRESSION NEURAL NETWORK UNTUK PREDIKSI TINGKAT PENCEMARAN UDARA KOTA SEMARANG
}

\author{
Budi Warsito ${ }^{1}$, Agus Rusgiyono ${ }^{1}$ dan M. Afif Amirillah ${ }^{2}$ \\ ${ }^{1}$ Program Studi Statistika FMIPA UNDIP \\ ${ }^{2}$ Alumni Program Studi Statistika FMIPA UNDIP
}

\begin{abstract}
This paper is discuss about General Regression Neural Network (GRNN) modelling to predict time series data, i.e. the air pollution rate in Semarang City comprises the floating dust, carbon monoxide (CO) and nitrogen monoxide (NO). The GRNN model have four processing layer that are input layer, pattern layer, summation layer and output layer. The input variable is determined by the ARIMA model. The result of GRNN modelling shows that the network have a good performance both at predict in sample and predict out of sample, that can be seen from the mean square error.
\end{abstract}

Keywords: GRNN, predict, air pollution

\section{Pendahuluan}

Udara yang tercemar dapat merusak lingkungan sekitarnya dan berpotensi mengganggu kesehatan masyarakat sekitar. Menurut Badan Lingkungan Hidup Dunia, United Nations Environmental Program (UNEP) pada tahun 1992 Indonesia berada pada urutan ketiga negara terpolusi di dunia setelah Mexico dan Thailand ${ }^{[5]}$. Kota Semarang merupakan salah satu dari enam kota di Indonesia dengan kualitas udara yang mengkhawatirkan, bahkan dinyatakan hanya memiliki udara bersih antara 22-62 hari dalam satu tahun ${ }^{[3]}$. Oleh karena itu perlu dilakukan studi untuk mengetahui model prediksi tingkat pencemaran udara di kota Semarang sehingga dapat dilakukan peramalan untuk masa-masa yang akan datang. Penelitian terdahulu ${ }^{1}$ telah mengindikasikan data kualitas udara merupakan proses stokhastik time series sehingga dimungkinkan untuk membuat peramalan data historis. Dengan mengetahui prediksi masa depan diharapkan dapat dilakukan kebijakan yang tepat sebagai langkah antisipasi.

Tulisan ini membahas pemodelan General Regression Neural Network (GRNN) yang merupakan salah satu model Jaringan Syaraf Tiruan (JST) untuk keperluan prediksi data time series tingkat pencemaran udara kota Semarang. Model GRNN terdiri dari empat layer pemrosesan yaitu input layer, pattern layer, summation layer dan output layer. Sebagai input model dipilih berdasarkan model terbaik ARIMA. Penggunaan fungsi aktivasi dilakukan pada pattern layer, sedangkan hasil aktivasi diringkas dalam summation layer yang meliputi penjumlahan aritmatik dan penjumlahan terboboti. Dari summation layer dapat dihitung output jaringan yang merupakan nilai prediksinya.

\section{General Regression Neural Network (GRNN)}

Teori General Regression Neural Network diperoleh dari estimasi densitas kernel multivariat dan regresi kernel multivariat ${ }^{[4]}$. Tujuan dari estimasi multivariat nonparametrik ini yaitu mengestimasi fungsi densitas probabilitas $\mathrm{F}\left(\mathrm{z}_{1}{ }^{*}, . ., \mathrm{z}_{\mathrm{m}}{ }^{*}\right)$ dari $\mathrm{m}$ variabel acak $\mathrm{z}=\left(\mathrm{z}_{1}, . ., \mathrm{z}_{\mathrm{m}}\right)^{\mathrm{T}}$ dengan menggunakan $n$ ukuran dari tiap variabel. Estimator densitas kernel multivariat pada kasus m dimensi didefinisikan sebagai 


$$
F\left(z^{*}\right)=\frac{1}{n} \sum_{i=1}^{n} \frac{1}{h_{1} \ldots h_{m}} K\left(\frac{z_{i 1}-z_{1}^{*}}{h_{1}}, \ldots, \frac{z_{i m}-z_{m}{ }^{*}}{h_{m 1}}\right)
$$

dimana $K$ adalah fungsi kernel multivariat dan panjang bidang (parameter penghalusan) vektor $\mathbf{h}=\left(\mathrm{h}_{1}, \ldots \mathrm{h}_{\mathrm{m}}\right)^{\mathrm{T}}$.

Data asli $\mathrm{Z}\left(\mathrm{X}_{\mathrm{i}}, \mathrm{Y}_{\mathrm{i}}\right)$; $\mathrm{i}=1, \ldots \mathrm{n}$ akan dibagi menjadi himpunan data pelatihan dan himpunan data pengujian. Himpunan data pelatihan digunakan untuk pengembangan model, sedangkan himpunan data pengujian digunakan untuk estimasi model yang berkualitas. Diasumsikan bahwa data pelatihan berasal dari suatu proses sampling yang mengukur nilai output dengan additive random noise:

$$
Z_{i}=E[Z \mid x, y]+\varepsilon_{i}
$$

dimana $\varepsilon_{i} \sim \operatorname{NID}\left(0, \sigma^{2}\right)$.

Mean bersyarat dari Z jika diberikan ke (x,y) yang dikenal sebagai suatu regresi Z pada $(\mathrm{x}, \mathrm{y})$ adalah suatu solusi yang meminimalkan MSE. Jika $\mathrm{f}(\mathrm{x}, \mathrm{y}, \mathrm{Z})$ adalah fungsi densitas probabilitas kontinu bersama maka mean bersyarat tersebut adalah:

$$
E[Z \mid x, y]=\frac{\int_{-\infty}^{\infty} Z \cdot f(x, y, Z) d Z}{\int_{-\infty}^{\infty} f(x, y, Z) d Z}
$$

Fungsi densitas $\mathrm{f}(\mathrm{x}, \mathrm{y}, \mathrm{Z})$ dapat diestimasi dari data dengan menggunakan estimator konsisten nonparametrik yang diusulkan oleh Parzen pada kasus dimensi banyak yang dikembangkan oleh Cacoullos ${ }^{[6]}$ sebagai berikut :

$$
f(x, y, Z)=\frac{1}{\left[(2 \pi)^{3 / 2} h^{3} n\right]} \sum_{i=1}^{n} \exp \left(-D_{i}^{2} / 2 h^{2}\right) \exp \left[-\left(Z-Z^{i}\right)^{2} / 2 h^{2}\right]
$$

Dengan $\mathrm{n}$ adalah banyaknya pengukuran dalam himpunan data pelatihan, $\mathrm{h}$ adalah suatu panjang bidang serta jarak metrik $\left(D_{i}^{2}\right)$ adalah:

$$
D_{i}^{2}=\left(x-x^{i}\right)^{2}+\left(y-y^{i}\right)^{2}
$$

Dengan mensubstitusi estimasi probabilitas bersama (4) kedalam mean bersyarat (3) diperoleh estimator kernel Nadaraya-Watson sebagai berikut :

$$
Z_{m}(X, Y)=\frac{\sum_{i=1}^{n} Z_{i} \exp \left(-D_{i}^{2} / 2 h^{2}\right)}{\sum_{i=1}^{n} \exp \left(-D_{i}^{2} / 2 h^{2}\right)}
$$

\section{Struktur dan Arsitektur GRNN}

GRNN terdiri dari empat lapisan unit pemroses, dimana tiap lapisan unit pemroses mempunyai fungsi komputasi khusus saat regresi nonlinier dibentuk. Lapisan pertama terdiri dari neuron-neuron input yang berfungsi untuk mengambil informasi. Neuron input ini bersifat unik untuk tiap variabel prediktor pada vektor input $X$. Tidak ada pengolahan data yang terjadi pada neuron-neuron input ini. Neuron-neuron input lalu meneruskan data menuju lapisan kedua yang dinamakan neuron pola. Sebuah neuron-neuron pola berfungsi mengkombinasikan dan memproses data secara sistematik dengan suatu fungsi aktivasi. Jumlah dari neuron pola sama dengan jumlah dari kasus dalam himpunan pelatihan. Neuron 
pola i berisi data dari neuron-neuron input dan menghitung output $\theta_{i}$ dengan menggunakan fungsi aktivasi dengan rumus:

$$
\theta_{i}=e^{-\left(X-U_{i}\right)^{\prime}\left(X-U_{i}\right) / 2 \sigma^{2}}
$$

dimana $X$ adalah vektor input dari variabel prediktor untuk GRNN, $U_{i}$ adalah vektor pelatihan yang diwakili neuron pola i dan $\sigma$ adalah parameter penghalusan.

Output dari neuron pola lalu dikirim menuju lapisan ketiga yang disebut summation neuron. Secara teknik, ada dua tipe summation yaitu simple arithmetic summation (jumlahan aritmatik sederhana) dan weighted summation (jumlahan terboboti).

Pada topologi GRNN, unit-unit pelatihan memisah untuk menyelesaikan simple arithmetic summation dan weighted summation. Formula dari simple arithmetic summation dan weighted summation adalah sebagai berikut :

$$
\begin{aligned}
& S_{S}=\sum_{i} \theta_{i} \\
& S_{W}=\sum_{i} W_{i} \theta_{i}
\end{aligned}
$$

dimana $S_{S}$ adalah simple arithmetic summation dan $S_{W}$ adalah weighted summation.

Jumlahan dari neuron-neuron summation lalu dikirim menuju lapisan keempat yang dinamakan neuron output. Neuron output lalu melakukan pembagian berikut untuk memperoleh output GRNN $y$ :

$$
y=\frac{S_{W}}{S_{S}}
$$

Arsitektur GRNN untuk satu unit output (univariat), yang digunakan untuk peramalan data runtun waktu disajikan pada gambar berikut :

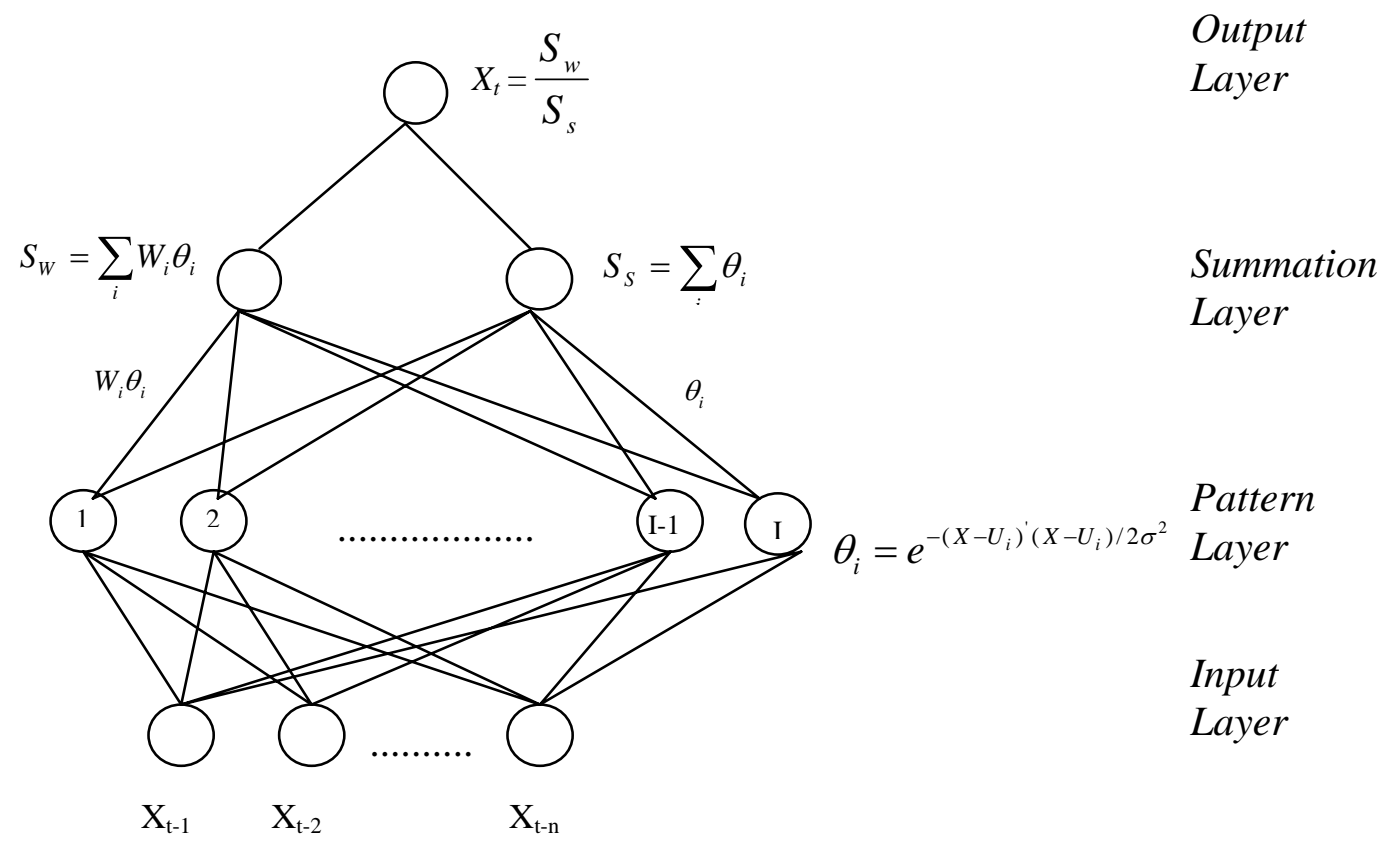

Gambar 1. Arsitektur GRNN untuk satu unit output (univariat) yang digunakan untuk peramalan data runtun waktu 


\section{Prediksi pada Data Pencemaran Udara Kota Semarang}

Dalam tulisan ini akan dijelaskan penentuan prediksi menggunakan metode GRNN untuk data pencemaran udara meliputi parameter debu, CO (Karbon Monoksida) dan NO (Nitrogen Monoksida) yang diambil pada Stasiun Pemantau Pencemaran Udara Banyumanik periode 1 Januari 2004 sampai peride 31 Mei 2004 di Kota Semarang. Variabel input dipilih berdasarkan model terbaik ARIMA untuk masing-masing parameter. Data diolah menggunakan software Matlab 6.5 menggunakan Neural Network Toolbox dengan fungsi newgrnn ${ }^{[2]}$ Hasil yang diperoleh dari model GRNN dibandingkan berdasarkan nilai MSE untuk prediksi dengan data pelatihan serta MSE untuk prediksi dengan data pengujian.

Pada parameter debu diperoleh model terbaik yaitu ARIMA $(1,1,2)$ sehingga diambil input data ke t-1 dan data ke t-2. Pada parameter CO diperoleh model terbaik yaitu ARIMA $(1,1,2)$ sehingga diambil input data ke $t-1$ dan data ke t-2. Sedangkan pada parameter NO diperoleh model terbaik yaitu ARIMA $(1,0,0)$ sehingga diambil input data ke t-1.

\section{Parameter Debu}

Pelatihan jaringan GRNN dengan input data debu diambil data ke t-1 dan data ke t-2, jaringan yang terbentuk terdiri dari dua unit input dengan masing-masing 92 data atau vektor inputnya dapat ditulis sebagai $X_{1}=\left(x_{1}, x_{2}, \ldots, x_{92}\right)$ dan $X_{2}=\left(v_{1}, v_{2}, \ldots, v_{92}\right)$ serta terdapat 92 neuron pada lapisan pola (pattern layer), sama dengan jumlah data pada himpunan data pelatihan. Pada pelatihan jaringan GRNN, dilakukan uji coba penggantian nilai spread untuk memperoleh nilai peramalan yang mendekati target. Setelah pelatihan dan pembelajaran jaringan yang terjadi pada lapisan pola dan lapisan jumlahan, jaringan lalu menghitung peramalan data debu pada periode t. Kemudian dilanjutkan pada pelatihan jaringan GRNN dengan input data debu pada data ke t-1 sehingga jaringan yang terbentuk terdiri dari satu unit input dengan 93 data atau vektor inputnya dapat ditulis sebagai $X_{1}=\left(x_{1}, x_{2}, \ldots, x_{93}\right)$ serta terdapat 93 neuron pada lapisan pola. Kemudian dilanjutkan pada pelatihan jaringan GRNN dengan input data debu pada data ke t-1, t-2 dan t-3 sehingga jaringan yang terbentuk terdiri dari tiga unit input dengan masing-masing 91 data atau vektor inputnya dapat ditulis sebagai $X_{1}=\left(x_{1}, x_{2}, \ldots, X_{91}\right), X_{2}=\left(v_{1}, v_{2}, \ldots, v_{91}\right)$ dan $X_{3}=\left(z_{1}, z_{2}, \ldots, z_{91}\right)$ serta terdapat 91 neuron pada lapisan pola. Tabel 1 menyajikan perbandingan MSE beberapa model GRNN dengan nilai spread yang berbeda. Pada tabel 2, disajikan perbandingan MSE beberapa model GRNN untuk input yang berbeda.

Tabel 1. Perbandingan MSE model GRNN data debu dengan nilai spread yang berbeda

\begin{tabular}{|c|c|c|c|c|c|c|c|}
\hline \multirow{2}{*}{ NO } & \multirow{2}{*}{$\begin{array}{c}\text { Nilai } \\
\text { Spread }\end{array}$} & \multicolumn{2}{|c|}{$\begin{array}{c}\text { Parameter Debu Input } \\
X_{t-1}\end{array}$} & $\begin{array}{c}\text { Parameter Debu Input } \\
X_{t-1} \text { dan } X_{t-2}\end{array}$ & \multicolumn{2}{c|}{$\begin{array}{c}\text { Parameter Debu Input } \\
X_{t-1}, X_{t-2} \text { dan } X_{t-3}\end{array}$} \\
\cline { 3 - 8 } & & $\begin{array}{c}\text { MSE } \\
\text { Pelatihan }\end{array}$ & $\begin{array}{c}\text { MSE } \\
\text { Pengujian }\end{array}$ & $\begin{array}{c}\text { MSE } \\
\text { Pelatihan }\end{array}$ & $\begin{array}{c}\text { MSE } \\
\text { Pengujian }\end{array}$ & $\begin{array}{c}\text { MSE } \\
\text { Pelatihan }\end{array}$ & $\begin{array}{c}\text { MSE } \\
\text { Pengujian }\end{array}$ \\
\hline \hline 1 & 1 & 78.8688 & 171.3641 & 76.4791 & 159.8941 & 71.6935 & 155.7609 \\
\hline 2 & 0.9 & 76.7337 & 165.7959 & 74.5994 & 154.4378 & 68.6694 & 151.2708 \\
\hline 3 & 0.8 & 74.6341 & 160.4813 & 72.5995 & 149.5535 & 64.8129 & 147.8599 \\
\hline 4 & 0.7 & 72.5785 & 155.4995 & 70.3853 & 145.6596 & $\mathbf{5 9 . 6 5 7 0}$ & $\mathbf{1 4 6 . 2 2 2 8}$ \\
\hline 5 & 0.6 & 70.5657 & 150.7309 & 67.8189 & 143.1925 & 52.3903 & 147.0953 \\
\hline 6 & 0.5 & 68.5654 & 146.0252 & $\mathbf{6 4 . 5 4 5 3}$ & $\mathbf{1 4 2 . 8 1 2 3}$ & 41.8401 & 151.8148 \\
\hline 7 & 0.4 & 66.4648 & 141.5510 & 59.6707 & 145.7129 & 27.8307 & 163.4018 \\
\hline 8 & 0.3 & 63.9931 & 137.8856 & 51.1878 & 152.8338 & 14.4119 & 183.2884 \\
\hline
\end{tabular}




\begin{tabular}{|c|c|c|c|c|c|c|c|}
9 & 0.2 & $\mathbf{6 0 . 5 1 8 0}$ & $\mathbf{1 3 6 . 1 2 2 8}$ & 33.5733 & 161.7439 & 5.3908 & 203.5822 \\
\hline 10 & 0.1 & 54.5008 & 141.2994 & 9.0069 & 170.2011 & 1.0813 & 215.4070 \\
\hline
\end{tabular}

Pada tabel 1 nilai MSE pelatihan turun sebanding dengan mengecilnya nilai spread, nilai MSE pengujian dengan input $X_{t-1}$ juga turun sampai pada nilai spread $=0.2$, setelah nilai spread lebih kecil dari 0.2, nilai MSE pengujian menjadi lebih besar dari nilai sebelumnya sehingga diperoleh nilai optimal untuk input $X_{t-1}$ yaitu pada nilai spread 0.2. Nilai MSE pengujian dengan input $X_{t-1}$ dan $X_{t-2}$ turun nilainya sebanding dengan mengecilnya nilai spread sampai pada nilai spread $=0.5$. Setelah nilai spread lebih kecil dari 0.5 , nilai MSE pengujian menjadi lebih besar dari nilai sebelumnya sehingga diperoleh nilai optimal untuk input $X_{t-1}$ dan $X_{t-2}$ yaitu pada nilai spread 0.5 .

Nilai MSE pengujian dengan input $X_{t-1}, X_{t-2}$ dan $X_{t-3}$ nilainya turun sebanding dengan mengecilnya nilai spread sampai pada nilai spread $=0.7$. Setelah nilai spread lebih kecil dari 0.7, nilai MSE pengujian menjadi lebih besar dari nilai sebelumnya sehingga diperoleh nilai optimal untuk input $X_{t-1}, X_{t-2}$ dan $X_{t-3}$ yaitu pada nilai spread 0.7.

Tabel 2. Perbandingan MSE model GRNN untuk input

yang berbeda pada data debu

\begin{tabular}{|c|c|c|}
\hline Input & MSE Pelatihan & MSE Pengujian \\
\hline \hline$X_{t-1}$ & $\mathbf{6 0 . 5 1 8 0}$ & $\mathbf{1 3 6 . 1 2 2 8}$ \\
\hline$X_{t-1}$ dan $X_{t-2}$ & 64.5453 & 142.8123 \\
\hline$X_{t-1}, X_{t-2} \operatorname{dan} X_{t-3}$ & 59.6570 & 146.2228 \\
\hline
\end{tabular}

Pada tabel 2 dapat dilihat bahwa nilai MSE pelatihan untuk input $X_{t-1}, X_{t-2}$ dan $X_{t-3}$ paling kecil, tetapi nilai MSE pengujian untuk input $X_{t-1}$ yang paling kecil. Pemodelan GRNN ini lebih berfokus pada ketepatan peramalan yang ditujukan pada perolehan MSE pengujian terkecil sehingga model yang dipilih yaitu model dengan input $X_{t-1}$ dan nilai spread $=0.2$.

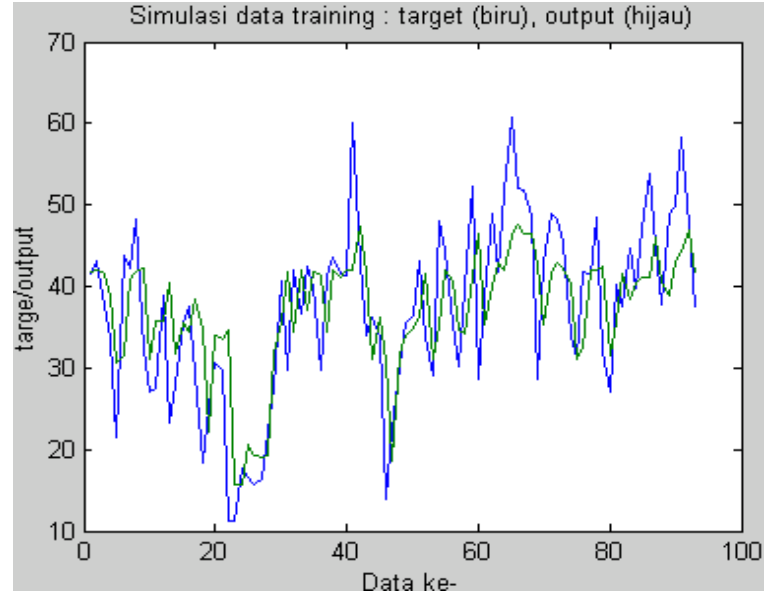

(a)

Gambar 2a. Plot hasil pelatihan model GRNN dengan input $X_{t-1}$ pada data debu

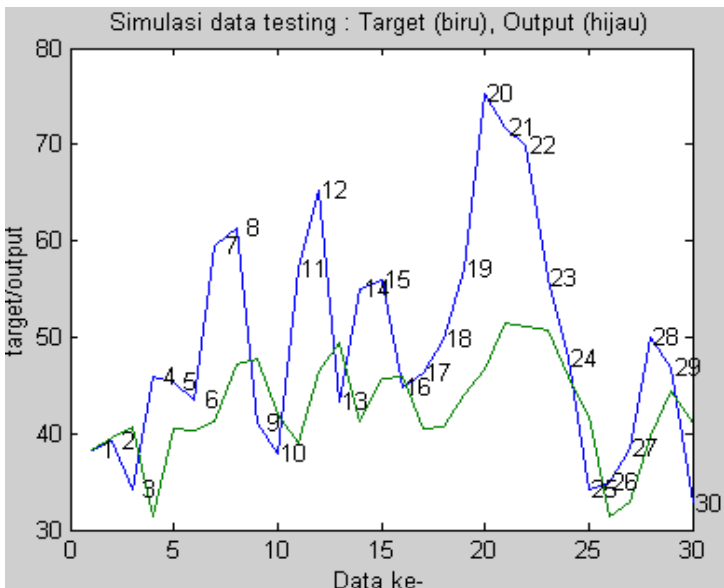

(b)

Gambar 2b. Plot hasil pengujian model GRNN dengan input $X_{t-1}$ pada data debu 
Pada gambar 2a dan 2b dapat dilihat perbandingan antara target dengan output jaringan untuk data pelatihan dan data pengujian saling berdekatan.

\section{Parameter CO}

Pada pelatihan jaringan GRNN dengan input data CO diambil data ke t-1 dan t-2, jaringan yang terbentuk terdiri dari dua unit input dengan masing-masing 120 data atau vektor inputnya dapat ditulis sebagai $X_{1}=\left(x_{1}, x_{2}, \ldots, x_{120}\right)$ dan $X_{2}=\left(v_{1}, v_{2}, \ldots, v_{120}\right)$ serta terdapat 120 neuron pada lapisan pola (pattern layer), sama dengan jumlah data pada himpunan data pelatihan. Kemudian dilanjutkan pada pelatihan jaringan GRNN dengan input data ke t-1 sehingga jaringan yang terbentuk terdiri dari satu unit input dengan 121 data atau vektor inputnya dapat ditulis sebagai $X_{1}=\left(x_{1}, x_{2}, \ldots, x_{121}\right)$ serta terdapat 121 neuron pada lapisan pola. Kemudian dilanjutkan pada pelatihan jaringan dengan input data ke t-1, t-2 dan t-3 sehingga jaringan yang terbentuk terdiri dari tiga unit input dengan masing-masing 119 data atau vektor inputnya dapat ditulis sebagai $X_{1}=\left(x_{1}, x_{2}, \ldots, X_{119}\right), X_{2}=\left(v_{1}, v_{2}, \ldots, v_{119}\right)$ dan $X_{3}=\left(z_{1}, z_{2}, \ldots, z_{119}\right)$ serta terdapat 119 neuron pada lapisan pola. Pada tabel 3, disajikan perbandingan MSE beberapa model GRNN dengan nilai spread yang berbeda. Pada tabel 4, disajikan perbandingan MSE beberapa model GRNN untuk input yang berbeda.

Tabel 3. Perbandingan MSE model GRNN data CO dengan nilai spread yang berbeda

\begin{tabular}{|c|c|c|c|c|c|c|c|}
\hline \multirow{2}{*}{ NO } & \multirow{2}{*}{$\begin{array}{c}\text { Nilai } \\
\text { Spread }\end{array}$} & \multicolumn{2}{|c|}{$\begin{array}{c}\text { Parameter CO Input } \\
\text { Xt-1 }\end{array}$} & \multicolumn{2}{c|}{$\begin{array}{c}\text { Parameter CO Input } \\
\text { Xt-1 dan Xt-2 }\end{array}$} & \multicolumn{2}{c|}{$\begin{array}{c}\text { Parameter CO Input } \\
\text { Xt-1; Xt-2 dan Xt-3 }\end{array}$} \\
\cline { 3 - 8 } & & $\begin{array}{c}\text { MSE } \\
\text { Pelatihan }\end{array}$ & $\begin{array}{c}\text { MSE } \\
\text { Pengujian }\end{array}$ & $\begin{array}{c}\text { MSE } \\
\text { Pelatihan }\end{array}$ & $\begin{array}{c}\text { MSE } \\
\text { Pengujian }\end{array}$ & $\begin{array}{c}\text { MSE } \\
\text { Pelatihan }\end{array}$ & $\begin{array}{c}\text { MSE } \\
\text { Pengujian }\end{array}$ \\
\hline \hline 1 & 1 & 0.0670 & 0.0538 & 0.0605 & 0.0536 & 0.0545 & 0.0535 \\
\hline 2 & 0.9 & 0.0657 & 0.0536 & 0.0583 & 0.0535 & $\mathbf{0 . 0 5 1 5}$ & $\mathbf{0 . 0 5 3 5}$ \\
\hline 3 & 0.8 & $\mathbf{0 . 0 6 4 4}$ & $\mathbf{0 . 0 5 3 5}$ & $\mathbf{0 . 0 5 5 9}$ & $\mathbf{0 . 0 5 3 5}$ & 0.0480 & 0.0537 \\
\hline 4 & 0.7 & 0.0631 & 0.0536 & 0.0531 & 0.0539 & 0.0436 & 0.0542 \\
\hline 5 & 0.6 & 0.0618 & 0.0539 & 0.0497 & 0.0547 & 0.0382 & 0.0554 \\
\hline 6 & 0.5 & 0.0606 & 0.0545 & 0.0456 & 0.0561 & 0.0317 & 0.0588 \\
\hline 7 & 0.4 & 0.0592 & 0.0554 & 0.0404 & 0.0587 & 0.0245 & 0.0688 \\
\hline 8 & 0.3 & 0.0575 & 0.0569 & 0.0331 & 0.0630 & 0.0159 & 0.0926 \\
\hline 9 & 0.2 & 0.0555 & 0.0586 & 0.0214 & 0.0718 & 0.0060 & 0.1253 \\
\hline 10 & 0.1 & 0.0514 & 0.0570 & 0.0067 & 0.1114 & 0.0003 & 0.1407 \\
\hline
\end{tabular}

Pada tabel 3 nilai MSE pelatihan turun sebanding dengan mengecilnya nilai spread, nilai MSE pengujian dengan input $X_{t-1}$ juga turun sampai pada nilai spread $=0.8$. Setelah nilai spread lebih kecil dari 0.8 , nilai MSE pengujian menjadi lebih besar dari nilai sebelumnya sehingga diperoleh nilai optimal untuk input $X_{t-1}$ pada nilai spread 0.8 .

Nilai MSE pengujian dengan input $X_{t-1}$ dan $X_{t-2}$ turun nilainya sebanding dengan mengecilnya nilai spread sampai pada nilai spread $=0.8$. Setelah nilai spread lebih kecil dari 0.8, nilai MSE pengujian menjadi lebih besar dari nilai sebelumnya sehingga diperoleh nilai optimal untuk input $X_{t-1}$ dan $X_{t-2}$ pada nilai spread 0.8 .

Nilai MSE pengujian dengan input $X_{t-1}, X_{t-2}$ dan $X_{t-3}$ pada nilai spread $=1$ nilainya sama dengan MSE pada nilai spread $=0.9$. Setelah nilai spread lebih kecil dari 0.9, nilai MSE pengujian menjadi lebih besar dari nilai sebelumnya sehingga diperoleh nilai optimal untuk input $X_{t-1}, X_{t-2}$ dan $X_{t-3}$ pada nilai spread 0.9. 
Tabel 4. Perbandingan MSE model GRNN untuk input yang berbeda pada data CO

\begin{tabular}{|c|c|c|}
\hline Input & MSE Pelatihan & MSE Pengujian \\
\hline \hline$X_{t-1}$ & 0.0644 & 0.0535 \\
\hline$X_{t-1}$ dan $X_{t-2}$ & 0.0559 & 0.0535 \\
\hline$X_{t-1}, X_{t-2}$ dan $X_{t-3}$ & $\mathbf{0 . 0 5 1 5}$ & $\mathbf{0 . 0 5 3 5}$ \\
\hline
\end{tabular}

Pada tabel 4 dapat dilihat bahwa MSE pelatihan input $X_{t-1}, X_{t-2}$ dan $X_{t-3}$ paling kecil daripada input yang lain. Pada MSE pengujian, nilainya sama untuk semua input. Sehingga model yang dipilih yaitu model dengan input $X_{t-1}, X_{t-2}$ dan $X_{t-3}$ dan nilai spread $=0.9$.

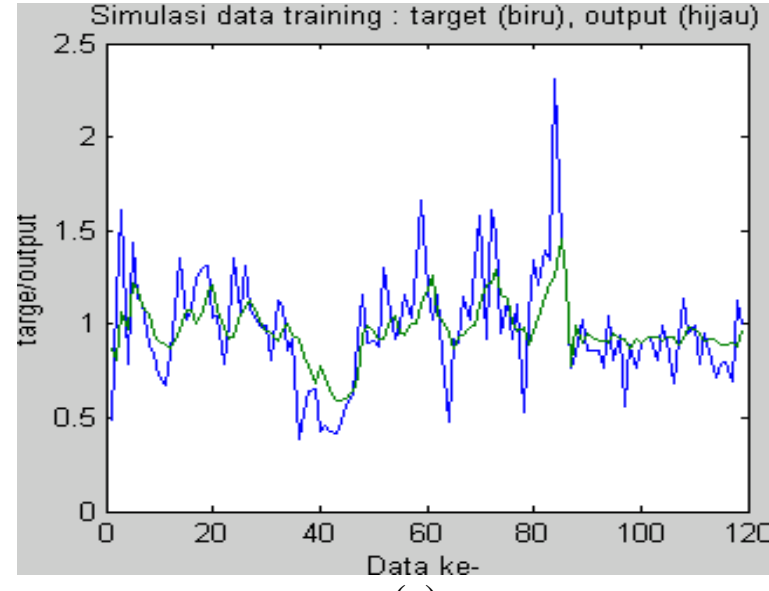

(a)

Gambar 3a. Plot hasil pelatihan model GRNN dengan input data $X_{t-1}$, $X_{t-2}$ dan $X_{t-3}$ pada data CO

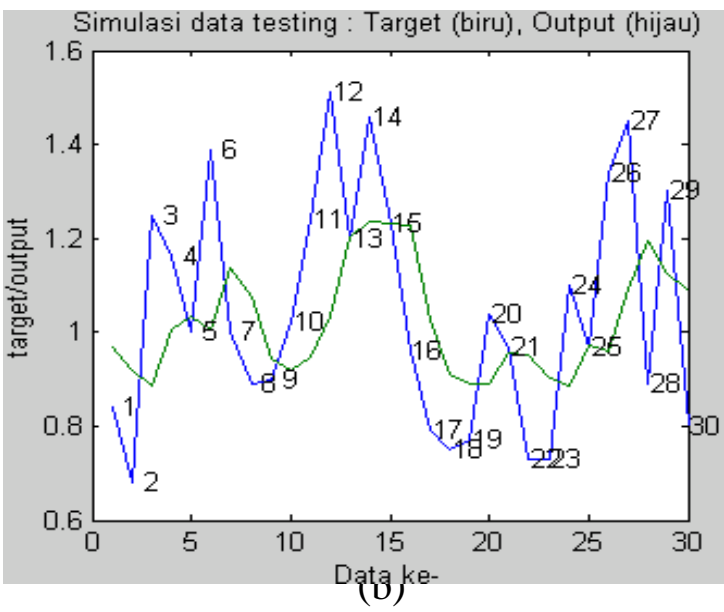

Gambar 3b. Plot hasil pengujian model GRNN dengan input data $X_{t-1}$, $X_{t-2}$ dan $X_{t-3}$ pada data CO

Pada gambar 3 dapat dilihat perbandingan antara target dengan output jaringan untuk data pelatihan dan data pengujian data CO saling berdekatan.

\section{Parameter NO}

Pada pelatihan jaringan GRNN data NO dengan input data ke t-1, jaringan yang terbentuk terdiri dari satu unit input dengan 121 data atau vektor inputnya dapat ditulis sebagai $X_{1}=\left(x_{1}, X_{2}, \ldots, X_{121}\right)$ serta terdapat 121 neuron pada lapisan pola (pattern layer). Kemudian dilanjutkan pada pelatihan jaringan dengan input data ke t-1 dan t-2 sehingga jaringan yang terbentuk terdiri dari dua unit input dengan masing-masing 120 data atau vektor inputnya dapat ditulis sebagai $X_{1}=\left(x_{1}, x_{2}, \ldots, x_{120}\right), X_{2}=\left(v_{1}, v_{2}, \ldots, v_{120}\right)$ serta terdapat 120 neuron pada lapisan pola. Tabel 5 menyajikan perbandingan MSE beberapa model GRNN dengan nilai spread yang berbeda. Pada tabel 6, disajikan perbandingan MSE beberapa model GRNN untuk input yang berbeda. 
Tabel 5. Perbandingan MSE model GRNN data NO dengan nilai spread yang berbeda

\begin{tabular}{|c|c|c|c|c|c|}
\hline \multirow{2}{*}{ NO } & \multirow{2}{*}{$\begin{array}{c}\text { Nilai } \\
\text { Spread }\end{array}$} & \multicolumn{2}{|c|}{$\begin{array}{c}\text { Parameter NO Input } \\
X_{\mathrm{t}-1}\end{array}$} & \multicolumn{2}{c|}{ Parameter NO Input } \\
\cline { 3 - 6 } & & $\begin{array}{c}\text { MSE } \\
\text { Pelatihan }\end{array}$ & $\begin{array}{c}\text { MSE } \\
\text { Pengujian }\end{array}$ & $\begin{array}{c}\text { MSE } \\
\text { Pelatihan }\end{array}$ & $\begin{array}{c}\text { MSE } \\
\text { Pengujian }\end{array}$ \\
\hline \hline 1 & 1 & 41.4328 & 47.3044 & 37.8336 & 49.2643 \\
\hline 2 & 0.9 & 40.7203 & 46.5182 & 36.1810 & 48.6128 \\
\hline 3 & 0.8 & 39.9014 & 45.7891 & $\mathbf{3 4 . 2 0 5 0}$ & $\mathbf{4 8 . 2 2 6 3}$ \\
\hline 4 & 0.7 & 38.9760 & 45.2227 & 31.8953 & 48.4863 \\
\hline 5 & 0.6 & $\mathbf{3 8 . 0 0 1 1}$ & $\mathbf{4 5 . 0 7 3 2}$ & 29.3465 & 50.1060 \\
\hline 6 & 0.5 & 37.0987 & 45.8161 & 26.6337 & 54.1733 \\
\hline 7 & 0.4 & 36.2692 & 47.5509 & 23.5238 & 61.4773 \\
\hline 8 & 0.3 & 35.1134 & 49.5201 & 19.2901 & 72.0858 \\
\hline 9 & 0.2 & 32.9648 & 52.8411 & 12.5560 & 84.2256 \\
\hline 10 & 0.1 & 27.5247 & 59.3128 & 3.7909 & 92.9568 \\
\hline 11 & 0.09 & 26.5418 & 60.3825 & 2.9953 & 93.7294 \\
\hline 12 & 0.08 & 25.4669 & 61.5747 & 2.2815 & 94.5376 \\
\hline 13 & 0.07 & 24.2993 & 63.1172 & 1.6818 & 95.3250 \\
\hline
\end{tabular}

Pada tabel 5 nilai MSE pelatihan turun sebanding dengan mengecilnya nilai spread, nilai MSE pengujian dengan input $X_{t-1}$ juga turun sampai pada nilai spread $=0.6$. Setelah nilai spread lebih kecil dari 0.6, nilai MSE pengujian menjadi lebih besar dari nilai sebelumnya sehingga diperoleh nilai optimal untuk input $X_{t-1}$ pada nilai spread 0.6.

Nilai MSE pengujian dengan input $X_{t-1}$ dan $X_{t-2}$ turun nilainya sebanding dengan mengecilnya nilai spread sampai pada nilai spread $=0.8$. Setelah nilai spread lebih kecil dari 0.8, nilai MSE pengujian menjadi lebih besar dari nilai sebelumnya sehingga diperoleh nilai optimal untuk input $X_{t-1}$ dan $X_{t-2}$ pada nilai spread 0.8.

Tabel 6. Perbandingan MSE model GRNN untuk input yang berbeda pada data NO

\begin{tabular}{|c|c|c|}
\hline Input & MSE Pelatihan & MSE Pengujian \\
\hline \hline$X_{t-1}$ & $\mathbf{3 8 . 0 0 1 1}$ & $\mathbf{4 5 . 0 7 3 2}$ \\
\hline$X_{t-1}$ dan $X_{t-2}$ & 34.2050 & 48.2263 \\
\hline
\end{tabular}

Pada tabel 6 dapat dilihat bahwa MSE pelatihan input $X_{t-1}$ dan $X_{t-2}$ paling kecil, akan tetapi nilai MSE pengujian untuk input $X_{t-1}$ lebih kecil daripada input $X_{t-1}$ dan $X_{t-2}$. Pada pemodelan GRNN ini lebih berfokus pada ketepatan peramalan yang ditujukan pada perolehan MSE pengujian terkecil sehingga model yang dipilih yaitu model dengan input $X_{t-1}$ dengan nilai spread $=0.6$. 


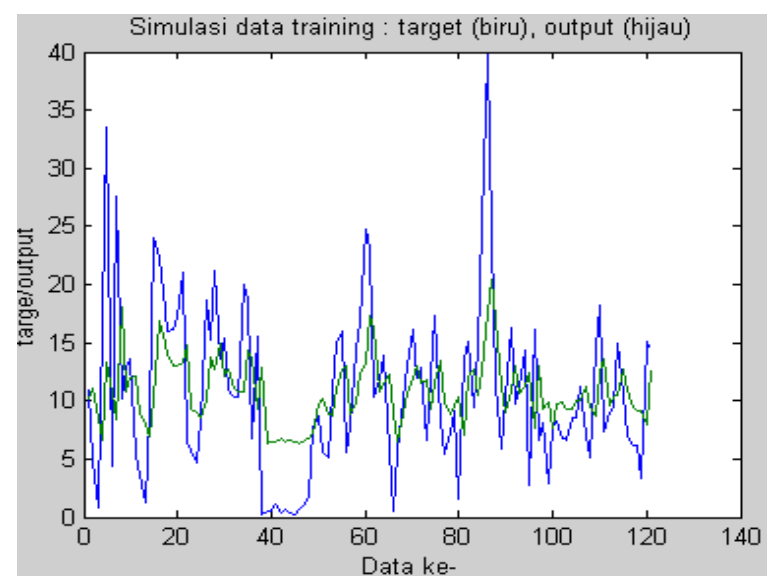

(a)

Gambar 4a. Plot hasil pelatihan model GRNN dengan input data $X_{t-1}$ pada data NO

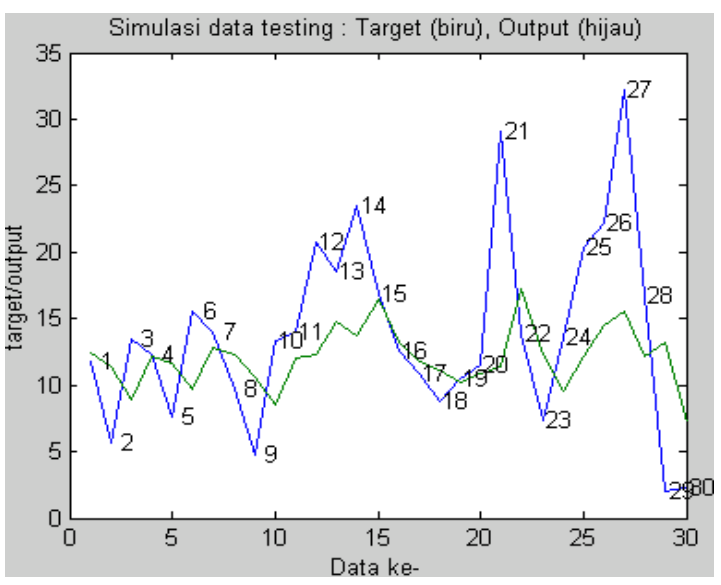

(b)

Gambar 4b. Plot hasil pengujian model GRNN dengan input data $X_{t-1}$ pada data NO

Pada gambar 4a dan 4b dapat dilihat perbandingan antara target dengan output jaringan untuk data pelatihan dan data pengujian data NO saling berdekatan.

\section{KESIMPULAN}

Pembahasan pada tulisan ini meliputi pembentukan model General Regression Neural Network (GRNN) dan penerapannya pada data runtun waktu. Hasil perhitungan terhadap data pencemaran udara di kota Semarang untuk parameter debu, CO dan NO menunjukkan bahwa model GRNN menghasilkan keakuratan prediksi yang cukup baik.

\section{DAFTAR PUSTAKA}

1. Barai, S.V., Dikshit, A.A., and Sharma, S., Neural Network Models for Air Quality Prediction : A Comparative Study, Working Paper, 2006.

2. Demuth, H. and Beale M., Neural Network Toolbox for Use in MATLAB, Mathwork, Inc., USA,1998.

3. Kompas, Polusi Udara Makin Mencemaskan - Kota Semarang Paling Parah, 3 Februari 2005.

4. Leung, M. T., Chen A. S. and Daouk H, Forecasting Exchange Rates Using General Regression Neural Network, University of Texas, USA.

5. Ozon, Indonesia Tak Jadi BebasTimbel, Februari 2003, Vol. 4, No. 5.

6. Specht, F. D., A General Regression Neural Network, IEEE Trans. Neural Network., Nov. 1991, Vol. 2, No.6: 568-576. 